\title{
EFFECT OF BETA-CAROTENE AND NUCLEOTIDE BASE SUPPLEMENTATION ON BLOOD COMPOSITION AND IMMUNE RESPONSE IN WEANED PIGS
}

\author{
Melinda ZOMBORSZKY-KOVÁCS ${ }^{1 *}$, L. BÁRDOS ${ }^{2}$, H. BíRÓ ${ }^{1}$, S. TUBOLY $^{3}$, \\ Erzsébet WOLF-TÁSKAI ${ }^{1}$ Á. TÓTH ${ }^{1}$ and P. SOÓs ${ }^{3}$ \\ ${ }^{1}$ Department of Animal Physiology and Hygiene, Faculty of Animal Science, \\ University of Kaposvár, H-7400 Kaposvár, P.O. Box 16, Hungary; ${ }^{2}$ Department of \\ Animal Physiology and Health, Faculty of Agricultural and Environmental Sciences, \\ Szent István University, Gödöllö; ${ }^{3}$ Department of Microbiology and Infectious Diseases, \\ Faculty of Veterinary Science, Szent István University, Budapest, Hungary
}

(Received September 29, 1999; accepted May 3, 2000)

\begin{abstract}
The effect of synthetic beta-carotene and synthetic nucleotide base on daily weight gain, feed consumption and certain haematological, biochemical and immunological parameters of piglets were studied in a 3-week experiment. Beginning one week prior to weaning, the diet fed to one experimental group of piglets was supplemented with $10 \%$ Rovimix Beta-carotene at $875 \mathrm{mg} / \mathrm{kg}$ of diet. Synthetic uracil and adenine (98\%, Sigma-Aldrich) were mixed into the diet of the other experimental group at doses of $500 \mathrm{mg} / \mathrm{kg}$ of diet for each substance. The control group received the basic diet without any supplementation. The changes observed over time in the haematological parameters and in certain biochemical variables could be regarded as physiological. By day 21 of the experiment, beta-carotene supplementation had significantly lowered the neutrophilic granulocyte percentage and elevated the lymphocyte percentage, while in the other two groups a change of opposite tendency occurred. At the end of the experimental period there was a decrease in plasma vitamin $\mathrm{E}$ concentration due to carotene supplementation (control: $6.1 \pm$ 1.5 , nucleotide: $6.3 \pm 2.5$, carotene: $2.3 \pm 1.5 \mathrm{mg} / \mathrm{L}$ ). Lymphocyte blastogenesis induced by phytohaemagglutinin and concanavalin A increased by 50 and $130 \%$, respectively, in the nucleotide group and by 60 and $30 \%$, respectively, in the carotene group, while it did not change in the control group. The supplements exerted no positive effect on the in vivo cellular immune response.
\end{abstract}

Key words: Nucleotide bases, beta-carotene, immune response, haematology, piglets

It is a generally known fact that there is a relationship between stress conditions, the immune responsiveness of an animal and certain frequently occurring disorders (Blecha, 1988). In such cases, stimulation of the immune response may lead to increased resistance to disease.

*E-mail: Melinda@atk.kaposvar.pate.hu; Fax: +36 (82) 320-175 
A number of chemicals (levamisole, imuthiol, avridine, isoprinosine, etc.) are known to exert a stimulating effect on immune system function (Blecha, 1988). Due to reservations concerning the application of such non-endogenous chemical substances, attention has now turned to the determination of the immunomodulatory effect and possible application of substances (vitamins, minerals, amino acids, etc.) naturally occurring in the organism (Burton et al., 1993; Finch and Turner, 1996; Kornegay et al., 1993).

In the experiment reported in this paper the effect exerted on immune system function by the supplementation of diets with synthetic beta-carotene and the synthetic nucleotide bases uracil and adenosine was studied in piglets. To monitor physiological conditions, changes in the differential and quantitative blood count and in certain biochemical parameters reflecting the state of metabolism were examined.

\section{Materials and methods}

\section{Experimental animals}

Unweaned 20 to 22-day-old piglets were divided into three groups in such a way that six healthy piglets of approximately identical weight, taken from each of two litters, were selected for each group ( $\mathrm{n}=12$ per group). Feeding of the experimental diets started 7 days prior to weaning; subsequently, after having been removed together from the litters, the animals were housed in batteries in which they were fed the experimental diets for further two weeks. The animals' health status was monitored, and the quantity of feed consumed per group as well as the individual body weight gain were recorded.

\section{Feeding}

The basic diet of one of the experimental groups (carotene group) was supplemented with $10 \%$ Rovimix Beta-carotene (Hoffmann-La Roche, $100 \mathrm{mg} / \beta$-carotene $\mathrm{g}$ ) at $875 \mathrm{mg} / \mathrm{kg}$ diet (10 times the recommendation of the NRC, 1988). Synthetic uracil and adenine (98\%, Sigma-Aldrich) were mixed into the diet of the other experimental group (nucleotide group) at doses of $500 \mathrm{mg} / \mathrm{kg}$ diet for each substance. The reason for the two nucleotide bases being given together lies in practical considerations; i.e., where a favourable effect emerges, there arises the possibility for the application of feedstuffs (e.g. meat or fish meal) or feed supplements (e.g. thermolysed brewer's yeast) of high nucleotide content. The control group received the basic diet without any supplementation. 


\section{Collection of samples}

Blood samples were taken from the vena cava cranialis on days 0,7 and 21 of the experimental period into tubes containing dipotassium ethylenediamine tetra-acetate (K-EDTA) or sodium-heparin.

\section{Haematological analyses}

The red blood cell (RBC) count, white blood cell (WBC) count, haemoglobin $(\mathrm{Hb})$ concentration, haematocrit value $(\mathrm{Htc})$, mean corpuscular volume (MCV), mean corpuscular haemoglobin $(\mathrm{MCH})$, and mean corpuscular haemoglobin concentration (MCHC) of erythrocytes of EDTA-blood were determined using flow scintillator Cobas Minos STE (Roche, Switzerland) calibrated for swine blood cells. Morphological examinations were carried out using blood smears stained by Pappenheim's method. The percentages of lymphocytes, neutrophils and other cell types were determined after counting 100 WBC microscopically in a blood smear.

\section{Biochemical parameters}

Determination of total protein (TP), albumin (ALB), urea, total cholesterol (TCh), and triglyceride (TG) concentration in the Na-heparin blood plasma was performed by means of a Centrifichem 600 analyser (Roche), while gammaglutamyl transferase (GGT), aspartate aminotransferase (AST) and alanine aminotransferase (ALT) activities were determined using a Kodak Ectachem $750 \times$ $\mathrm{RC}$ analyser with Johnson \& Johnson slides.

\section{Plasma retinoid and vitamin E content}

Plasma retinol (ROL), retinyl palmitate (RP) and vitamin E concentrations were determined by isocratic adsorption HPLC using the method of Biesalski et al. (1986). For the measurement of $\beta$-carotene the same extraction and chromatographic parameters as proposed by Biesalski et al. (1986) were used, and detection was performed at a wavelength of $450 \mathrm{~nm}$.

\section{Immunological parameters}

In order to investigate in vitro cellular immune responsiveness, blastogenic transformation of lymphocytes induced by $200 \mu \mathrm{g}$ per ml phytohaemagglutinin (PHA, Sigma-Aldrich) or concanavalin A (Con A, Sigma-Aldrich) was measured by the lymphocyte stimulation test (LST). The rate of blastogenic response was determined by the fluorometric DNA assay (Nagahata et al., 1987).

In vivo cellular immune response was studied by an intradermal test. A $0.1 \mathrm{ml}$ volume of PHA solution $(500 \mu \mathrm{g}$ phytohaemagglutinin $\mathrm{M}$ dissolved in $1 \mathrm{ml}$ purified bovine serum) was injected into the skin of the neck on the last day 
of the experiment. Skin fold thickness (mm) was measured with velnier callipers at $24 \mathrm{~h}$ post-injection.

\section{Statistical analysis}

Statistical analyses were performed using the SPSS programme package (1996). Differences between groups and between blood samplings were determined by paired $t$-test and by the Kruskal-Wallis Test for analysis of variance.

\section{Results}

The state of health of the animals was judged to be satisfactory throughout the entire experimental period.

Significantly $(\mathrm{P}<0.05)$ higher weight gain was recorded in the carotene and nucleotide groups subsequent to weaning $(3.74$ and $3.31 \mathrm{~kg}$, respectively, as compared to $2.37 \mathrm{~kg}$ in the control group). The feed intake was also greater in the experimental groups (56.9 and $57.3 \mathrm{~kg}$, respectively, per group in comparison with $47.2 \mathrm{~kg}$ for the control group).

Of the haematological parameters of erythrocytes (Table 1), the RBC count first decreased and subsequently increased in the control and in the nucleotide groups. With respect to the data recorded on day 0 , significant $(\mathrm{P}<0.05)$ differences between the groups were measured in the $\mathrm{Hb}, \mathrm{Htc}, \mathrm{MCH}$ and $\mathrm{MCV}$ values. Therefore, differences between the groups at day 7 and 21 were not compared directly, instead, percentage change was calculated in relation to the initially recorded values. The differences observed at the 2 nd blood sampling (on the 7th day) in $\mathrm{RBC}, \mathrm{Hb}$ and $\mathrm{Htc}$ disappeared by the end of the experimental period, and none of the parameters measured on the 21 st day showed any significant difference attributable to the supplementation applied.

In the control group and in the nucleotide group the ratio of neutrophilic granulocytes had increased and that of lymphocytes decreased by day 21 of the experiment (Table 2). The differential blood count of the carotene group showed an opposite change: the proportion of neutrophils decreased significantly while that of lymphocytes rose. In none of the cases did the percentage of eosinophils, basophils and monocytes exceed 5\%.

Of the biochemical parameters examined (Table 3), changes within the physiological limit values which occurred over time were a decrease in TP, ALB, $\mathrm{TCh}$ and $\mathrm{TG}$, and an increase in urea concentration. At the 1st blood sampling significant differences between the groups were found in the urea, TCh and GGT values. With respect to the values measured on the 21 st day, expressed in terms of percentage change in relation to the initial values, the differences remained significant. 
Table 1

Haematological parameters and their changes (\%) compared to day 0 (as $100 \%$ )

\begin{tabular}{|c|c|c|c|c|c|c|c|}
\hline \multicolumn{2}{|c|}{$\begin{array}{c}\text { Parameter } \\
\text { (Day of sampling) }\end{array}$} & \multicolumn{2}{|c|}{$\begin{array}{c}\text { Control } \\
\text { means } \pm \text { S.D. }\end{array}$} & \multicolumn{2}{|c|}{$\begin{array}{c}\text { Carotene } \\
\text { means } \pm \text { S.D. }\end{array}$} & \multicolumn{2}{|c|}{$\begin{array}{l}\text { Nucleotide } \\
\text { means } \pm \text { S.D. }\end{array}$} \\
\hline $\begin{array}{r}(0) \\
(7) \\
(21)\end{array}$ & $10^{6} / \mu \mathrm{L}$ & $\begin{array}{c}5.0 \pm 0.6 \\
93^{\mathrm{b}} \pm 5 \\
110^{\mathrm{a}} \pm 20\end{array}$ & $\left(100^{\mathrm{a}}\right)$ & $\begin{array}{c}5.0 \pm 0.56 \\
105^{\mathrm{b}} \pm 6 \\
109^{\mathrm{b}} \pm 9\end{array}$ & $\left(100^{\mathrm{a}}\right)$ & $\begin{array}{c}4.6 \pm 0.86 \\
93^{\mathrm{b}} \pm 6 \\
120^{\mathrm{a}} \pm 18\end{array}$ & $\left(100^{\mathrm{a}}\right)$ \\
\hline $\begin{array}{r}(0) \\
(7) \\
(21)\end{array}$ & $\mathrm{g} / \mathrm{L}$ & $\begin{array}{l}87.0 \pm 106 \\
83^{\mathrm{b}} \pm 4 \\
93^{\mathrm{ab}} \pm 19\end{array}$ & $\left(100^{\mathrm{a}}\right)$ & $\begin{array}{l}97.4 \pm 56 \\
90^{\mathrm{b}} \pm 4 \\
90^{\mathrm{b}} \pm 14\end{array}$ & $\left(100^{\mathrm{a}}\right)$ & $\begin{array}{l}83.3 \pm 13 \\
81 \pm 6 \\
93 \pm 10\end{array}$ & (100) \\
\hline $\begin{array}{r}(0) \\
(7) \\
(21)\end{array}$ & $\%$ & $\begin{array}{l}29.1 \pm 3.26 \\
85^{\mathrm{b}} \pm 4 \\
96^{\mathrm{ab}} \pm 19\end{array}$ & $\left(100^{\mathrm{a}}\right)$ & $\begin{array}{l}32.4 \pm 2.16 \\
93^{b} \pm 5 \\
94^{b} \pm 12\end{array}$ & $\left(100^{\mathrm{a}}\right)$ & $\begin{array}{l}27.7 \pm 4.36 \\
86^{\mathrm{b}} \pm 5 \\
98^{\mathrm{a}} \pm 11\end{array}$ & $\left(100^{\mathrm{a}}\right)$ \\
\hline $\begin{array}{ll}\mathrm{MCH} & (0) \\
& (7) \\
& (21)\end{array}$ & pg & $\begin{array}{l}17.5 \pm 1.4 \\
89^{b} \pm 3 \\
84^{b} \pm 8\end{array}$ & $\left(100^{\mathrm{a}}\right)$ & $\begin{array}{l}19.6 \pm 1.7 \\
86^{\mathrm{b}} \pm 4 \\
82^{\mathrm{b}} \pm 11\end{array}$ & $\left(100^{\mathrm{a}}\right)$ & $\begin{array}{l}18.1 \pm 1.7 \\
87^{b} \pm 4 \\
84^{b} \pm 12\end{array}$ & $\left(100^{\mathrm{a}}\right)$ \\
\hline $\begin{array}{r}\text { MCHC }(0) \\
(7) \\
(21)\end{array}$ & $\mathrm{g} / \mathrm{L}$ & $\begin{array}{r}298 \pm 6 \\
97 \pm 2 \\
97 \pm 3\end{array}$ & (100) & $\begin{array}{c}300 \pm 11 \\
97 \pm 3 \\
96 \pm 4\end{array}$ & (100) & $\begin{array}{r}300 \pm 8 \\
95 \pm 2 \\
95 \pm 4\end{array}$ & (100) \\
\hline $\begin{array}{ll}M C V & (0) \\
& (7) \\
& (21)\end{array}$ & $\mathrm{fL}$ & $\begin{array}{l}59 \pm 4 \\
92^{b} \pm 3 \\
87^{c} \pm 6\end{array}$ & $\left(100^{\mathrm{a}}\right)$ & $\begin{array}{l}65 \pm 4 \\
89^{\mathrm{b}} \pm 2 \\
86^{\mathrm{b}} \pm 8\end{array}$ & $\left(100^{\mathrm{a}}\right)$ & $\begin{array}{l}60 \pm 5 \\
92^{\mathrm{b}} \pm 4 \\
89^{\mathrm{b}} \pm 9\end{array}$ & $\left(100^{\mathrm{a}}\right)$ \\
\hline
\end{tabular}

Note: Different superscripts denote significant $(\mathrm{P}<0.05)$ differences between blood samplings within groups. The data obtained on day 0 of sampling denote absolute values $(=100 \%)$, while those relating to the 7 th and 21 st sampling days are values calculated as percentages of the initial values

Table 2

Differential white blood cell count (means \pm S. D.)

\begin{tabular}{lcccc}
\hline Groups & $\begin{array}{c}\text { Sampling } \\
\text { (day) }\end{array}$ & $\begin{array}{c}\text { Control } \\
\text { means } \pm \text { S.D. }\end{array}$ & $\begin{array}{c}\text { Carotene } \\
\text { means } \pm \text { S.D. }\end{array}$ & $\begin{array}{c}\text { Nucleotide } \\
\text { means } \pm \text { S.D. }\end{array}$ \\
\hline WBC $\left(10^{3} / \mu \mathrm{L}\right)$ & 0 & $6.9^{\mathrm{a}} \pm 4.0$ & $7.4^{\mathrm{a}} \pm 1.3$ & $6.9^{\mathrm{a}} \pm 1.8$ \\
& 21 & $12.7^{\mathrm{b}} \pm 8.0$ & $12.6^{\mathrm{b}} \pm 1.6$ & $11.9^{\mathrm{b}} \pm 2.3$ \\
Neutrophils (\%) & 0 & $43.2^{\mathrm{a}} \pm 14.3$ & $43.1^{\mathrm{a}} \pm 9.4$ & $40.1^{\mathrm{a}} \pm 14.1$ \\
& 21 & $50.8^{\mathrm{b}} \pm 8.7$ & $33.0^{\mathrm{c}} \pm 6.4$ & $46.8^{\mathrm{b}} \pm 7.1$ \\
& & & & \\
Lymphocytes (\%) & 0 & $55.8^{\mathrm{a}} \pm 15.4$ & $56.2^{\mathrm{a}} \pm 10.6$ & $58.7^{\mathrm{a}} \pm 13.5$ \\
& 21 & $48.3^{\mathrm{b}} \pm 9.5$ & $63.9^{\mathrm{c}} \pm 5.9$ & $50.2^{\mathrm{b}} \pm 7.8$ \\
\hline
\end{tabular}

Note: Different superscripts denote significant $(\mathrm{P}<0.05)$ differences between blood samplings and groups 
Table 3

Biochemical parameters in the blood plasma and their changes (\%) compared to day 0 (as $100 \%$ )

\begin{tabular}{|c|c|c|c|c|c|c|c|c|}
\hline \multicolumn{3}{|c|}{$\begin{array}{c}\text { Parameter } \\
\text { (Day of sampling) }\end{array}$} & \multicolumn{2}{|c|}{$\begin{array}{c}\text { Control } \\
\text { means } \pm \text { S.D. }\end{array}$} & \multicolumn{2}{|c|}{$\begin{array}{c}\text { Carotene } \\
\text { means } \pm \text { S.D. }\end{array}$} & \multicolumn{2}{|c|}{$\begin{array}{c}\text { Nucleotide } \\
\text { means } \pm \text { S.D. }\end{array}$} \\
\hline TP & $\begin{array}{r}(0) \\
(7) \\
(21)\end{array}$ & $\mathrm{g} / \mathrm{L}$ & $\begin{array}{l}50.5 \pm 5.5 \\
94^{\mathrm{b}} \pm 7 \\
92^{\mathrm{b}} \pm 13\end{array}$ & $\left(100^{\mathrm{a}}\right)$ & $\begin{array}{l}46.9 \pm 4.8 \\
98 \pm 7 \\
96 \pm 9\end{array}$ & $(100)$ & $\begin{array}{l}52.7 \pm 4.7 \\
94^{\mathrm{b}} \pm 5 \\
92^{\mathrm{b}} \pm 9\end{array}$ & $\left(100^{\mathrm{a}}\right)$ \\
\hline ALB & $\begin{array}{r}(0) \\
(7) \\
(21)\end{array}$ & $\mathrm{g} / \mathrm{L}$ & $\begin{array}{c}36.4 \pm 3.6 \\
100^{\mathrm{a}} \pm 8 \\
90^{\mathrm{b}} \pm 10\end{array}$ & $\left(100^{\mathrm{a}}\right)$ & $\begin{array}{l}34.8 \pm 3.8 \\
99 \pm 10 \\
94 \pm 11\end{array}$ & $(100)$ & $\begin{array}{c}37.4 \pm 4.7 \\
104 \pm 5 \\
94 \pm 10\end{array}$ & (100) \\
\hline TCh & $\begin{array}{l}(0) \\
(7) \\
(21)\end{array}$ & $\mathrm{mmol} / \mathrm{L}$ & $\begin{array}{l}2.5 \pm 0.5 \\
94^{\mathrm{a}} \pm 16 \\
70^{\mathrm{b}} \pm 15\end{array}$ & $\left(100^{\mathrm{a}}\right)$ & $\begin{array}{l}3.8 \pm 1.0 \\
67^{\mathrm{b}} \pm 17 \\
38^{\mathrm{c}} \pm 10\end{array}$ & $\left(100^{\mathrm{a}}\right)$ & $\begin{array}{l}3.0 \pm 0.9 \\
89^{\mathrm{ab}} \pm 27 \\
57^{\mathrm{b}} \pm 17\end{array}$ & $\left(100^{\mathrm{a}}\right)$ \\
\hline TG & $\begin{array}{r}(0) \\
(7) \\
(21)\end{array}$ & $\mathrm{mmol} / \mathrm{L}$ & $\begin{array}{l}1.2 \pm 0.4 \\
89^{\mathrm{a}} \pm 43 \\
45^{\mathrm{b}} \pm 23\end{array}$ & $\left(100^{\mathrm{a}}\right)$ & $\begin{array}{l}1.2 \pm 0.4 \\
80^{\mathrm{b}} \pm 13 \\
40^{\mathrm{c}} \pm 19\end{array}$ & $\left(100^{\mathrm{a}}\right)$ & $\begin{array}{l}1.3 \pm 0.5 \\
81^{\mathrm{a}} \pm 34 \\
38^{\mathrm{b}} \pm 22\end{array}$ & $\left(100^{\mathrm{a}}\right)$ \\
\hline Urea & $\begin{array}{l}(0) \\
(7) \\
(21)\end{array}$ & $\mathrm{mmol} / \mathrm{L}$ & $\begin{aligned} 3.7 & \pm 1.4 \\
83 & \pm 21 \\
109 & \pm 77\end{aligned}$ & $(100)$ & $\begin{array}{l}2.0 \pm 0.5 \\
107^{\mathrm{a}} \pm 22 \\
177^{\mathrm{b}} \pm 65\end{array}$ & $\left(100^{\mathrm{a}}\right)$ & $\begin{array}{r}3.1 \pm 0.7 \\
102^{\mathrm{a}} \pm 35 \\
127^{\mathrm{b}} \pm 31\end{array}$ & $\left(100^{\mathrm{a}}\right)$ \\
\hline GGT & $\begin{array}{l}(0) \\
(7) \\
(21)\end{array}$ & $\mathrm{U} / \mathrm{L}$ & $\begin{array}{c}42 \pm 9 \\
113 \pm 21 \\
116 \pm 18\end{array}$ & $(100)$ & $\begin{array}{l}71 \pm 17 \\
84^{\mathrm{ab}} \pm 21 \\
72^{\mathrm{b}} \pm 13\end{array}$ & $\left(100^{\mathrm{a}}\right)$ & $\begin{array}{r}44 \pm 20 \\
107 \pm 42 \\
110 \pm 18\end{array}$ & (100) \\
\hline AST & $\begin{array}{r}(0) \\
(7) \\
(21)\end{array}$ & $\mathrm{U} / \mathrm{L}$ & $\begin{array}{l}39 \pm 11 \\
78^{\mathrm{b}} \pm 19 \\
90^{\mathrm{a}} \pm 21\end{array}$ & $\left(100^{\mathrm{a}}\right)$ & $\begin{array}{c}39 \pm 9 \\
90^{\mathrm{a}} \pm 21 \\
115^{\mathrm{b}} \pm 33\end{array}$ & $\left(100^{\mathrm{a}}\right)$ & $\begin{array}{r}41 \pm 10 \\
98 \pm 28 \\
112 \pm 38\end{array}$ & (100) \\
\hline ALT & $\begin{array}{r}(0) \\
(7) \\
(21)\end{array}$ & $\mathrm{U} / \mathrm{L}$ & $\begin{array}{c}53 \pm 9 \\
106^{\mathrm{a}} \pm 18 \\
167^{\mathrm{b}} \pm 42\end{array}$ & $\left(100^{\mathrm{a}}\right)$ & $\begin{array}{c}52 \pm 5 \\
124^{\mathrm{b}} \pm 18 \\
182^{\mathrm{c}} \pm 27\end{array}$ & $\left(100^{\mathrm{a}}\right)$ & $\begin{array}{c}52 \pm 11 \\
108^{\mathrm{a}} \pm 15 \\
188^{\mathrm{b}} \pm 55\end{array}$ & $\left(100^{\mathrm{a}}\right)$ \\
\hline
\end{tabular}

Note: Different superscript denote significant $(\mathrm{P}<0.05)$ differences between blood samplings. The data obtained on day 0 of sampling denote absolute values $(=100 \%)$, while those relating to the 7 th and 21 st sampling days are values calculated as percentages of the initial values

Beta-carotene was not detectable in the plasma even in the animals consuming the carotene-supplemented diet.

The concentration of retinyl palmitate (RP) and retinol (ROL) rose in all the three groups. Between days 7 and 21 , the rise occurring as a result of carotene supplementation was markedly lower (Table 4). In this case already the plasma retinoid level was higher because the animals had received the carotenesupplemented diet for 7 days before the start of the study (on days 1-7 of the ex- 
periment). No significant differences were demonstrable between the groups in the concentrations measured on day 21 of the experiment, except in the nucleotide group which had significantly higher RP concentration compared to the other two groups.

Vitamin E concentration decreased in the carotene group while it increased in the other two groups. At the time of the third blood sampling a substantial and statistically significant difference was found between the groups in serum vitamin E level.

Table 4

Retinyl palmitate (RP), retinol (ROL) and vitamin E concentrations of the serum (means \pm S. D.)

\begin{tabular}{lcccc}
\hline \multicolumn{1}{c}{ Groups } & Sampling (day) & $\begin{array}{c}\text { Control } \\
\text { means } \pm \text { S.D. }\end{array}$ & $\begin{array}{c}\text { Carotene } \\
\text { means } \pm \text { S.D. }\end{array}$ & $\begin{array}{c}\text { Nucleotide } \\
\text { means } \pm \text { S.D. }\end{array}$ \\
\hline RP $(\mu \mathrm{g} / \mathrm{L})$ & 7 & $234^{\mathrm{a}} \pm 53$ & $763 \pm 390$ & $298^{\mathrm{a}} \pm 44$ \\
& 21 & $884^{\mathrm{b}} \pm 178$ & $833 \pm 407$ & $1154^{\mathrm{b}} \pm 246$ \\
$\mathrm{ROL}(\mu \mathrm{g} / \mathrm{L})$ & 7 & $76^{\mathrm{a}} \pm 12$ & $182 \pm 92$ & $85^{\mathrm{a}} \pm 26$ \\
& 21 & $408^{\mathrm{b}} \pm 151$ & $379 \pm 238$ & $446^{\mathrm{b}} \pm 249$ \\
Vitamin E $(\mathrm{mg} / \mathrm{L})$ & 7 & $2.5^{\mathrm{a}} \pm 0.9$ & $3.0^{\mathrm{a}} \pm 0.6$ & $3.9^{\mathrm{a}} \pm 1.8$ \\
& 21 & $6.1^{\mathrm{b}} \pm 1.5$ & $2.3^{\mathrm{b}} \pm 1.5$ & $6.3^{\mathrm{b}} \pm 2.5$ \\
\hline
\end{tabular}

Note: Different superscripts denote significant $(\mathrm{P}<0.05)$ differences between blood samplings within groups

The LST values obtained with PHA and Con A increased by 50 and $130 \%$, respectively, in the nucleotide group and by 60 and 30\% (not significant), respectively, in the carotene group, while the blastogenic transformation of lymphocytes did not change in the control group (Table 5).

The intradermal PHA test carried out after the third blood sampling revealed a significantly lower response in the carotene group compared to the control and the nucleotide group (Table 5).

\section{Discussion}

The significantly higher weight gain recorded in the carotene and nucleotide groups subsequent to weaning was attributable to the greater feed intake in the experimental groups.

The changes in the haematological and biochemical parameters examined with the progress of time can be regarded as physiological.

Even in the group receiving carotene supplementation, beta-carotene level of the blood plasma could be detected only at a level falling within the margin of 
error of the method applied and, therefore, the beta-carotene values of the plasma could not be demonstrated. Despite the fact that we could not detect betacarotene in the blood, it is completely certain that, besides its substantial transformation into retinoids, this compound is efficiently absorbed also in the pig, as has been proved by the monitoring of radiolabelled beta-carotene and retinol (Schweigert et al., 1995).

Table 5

LST values after stimulation of lymphocytes with PHA and Con A and results of the intradermal PHA test (means \pm S. D.)

\begin{tabular}{lcccc}
\hline \multicolumn{1}{c}{ Groups } & $\begin{array}{c}\text { Sampling } \\
(\text { day })\end{array}$ & $\begin{array}{c}\text { Control } \\
\text { means } \pm \text { S.D. }\end{array}$ & $\begin{array}{c}\text { Carotene } \\
\text { means } \pm \text { S.D. }\end{array}$ & $\begin{array}{c}\text { Nucleotide } \\
\text { means } \pm \text { S.D. }\end{array}$ \\
\hline LST (PHA) \% & 0 & $2.78 \pm 1.18$ & $2.59^{\mathrm{a}} \pm 0.58$ & $2.43^{\mathrm{a}} \pm 0.74$ \\
& 7 & $2.87 \pm 0.38$ & $3.34^{\mathrm{ab}} \pm 1.04$ & $3.12^{\mathrm{ab}} \pm 1.27$ \\
& 21 & $2.95 \pm 0.62$ & $4.20^{\mathrm{b}} \pm 1.17$ & $3.59^{\mathrm{b}} \pm 1.34$ \\
& 0 & $1.19 \pm 0.50$ & $0.97 \pm 0.22$ & $0.87^{\mathrm{a}} \pm 0.24$ \\
LST (Con A) \% & 7 & $1.22 \pm 0.24$ & $1.18 \pm 0.25$ & $1.85^{\mathrm{b}} \pm 0.65$ \\
& 21 & $1.13 \pm 0.19$ & $1.27 \pm 0.61$ & $1.98^{\mathrm{b}} \pm 0.91$ \\
Skin fold thickness (mm) & 21 & $4.77^{\mathrm{A}} \pm 1.58$ & $2.59^{\mathrm{B}} \pm 1.35$ & $4.21^{\mathrm{AB}} \pm 2.21$ \\
\hline
\end{tabular}

Note: Different superscripts denote significant $(\mathrm{P}<0.05)$ differences between blood samplings $(\mathrm{a}$, b) or groups (A, B)

The two T-cell mitogens reflect the general cellular immune responsiveness of the organism. The results of this experiment are consistent with data published in a number of reports, according to which both nucleotide and betacarotene supplementation result in an increase in T-cell immune responsiveness (Bendich and Shapiro, 1986; Barankiewicz and Cohen, 1987; Pérignon et al., 1987; Hoskinson et al., 1989; Daniel et al., 1991a, b; Michal et al., 1994). Betacarotene is deposited in the lymphocytes, and acts as an immunostimulant through its membrane-protecting and blastogenesis-promoting effects (Chew et al., 1993). Studying the effect of a single injection of 0,20 and $40 \mathrm{mg}$ betacarotene to pigs, Chew et al. (1991a, $b$ ) have demonstrated that lymphocytes take up substantial quantities of beta-carotene, unlike neutrophilic granulocytes and erythrocytes in which beta-carotene could not be detected. The retinol and alphatocopherol concentration of the blood plasma and blood cells did not change, which indicates that beta-carotene exerts an effect on blood cells which is independent of the vitamin A effect. Beta-carotene supplementation had no effect on vitamin E content of the plasma in calves (Chew et al., 1993) and in humans (Willett et al., 1983), while in rats (Bendich and Shapiro, 1986) and in chickens (Mayne and Parker, 1986) it lowered the plasma level of vitamin E. 
Blair et al. (1996) studied the effect of supplementing the diet of pigs with beta-carotene and vitamin $\mathrm{A}$, and found no changes in the cellular immune response given to nonspecific mitogens. They explained this finding, which is at variance with the results reported above, by the transformation of beta-carotene into vitamin A by the intestinal epithelial cells. Vitamin A does not have an immune response enhancing effect; moreover, when applied in higher concentrations it significantly lowered the vitamin E level of the blood plasma.

In the present experiment dietary carotene supplementation did not alter the plasma vitamin A level. At the same time, the concentration of vitamin $\mathrm{E}$ in the carotene-supplemented group declined to less than half of the mean value of the other two groups $(2.3 \mathrm{mg} / \mathrm{L})$. That value is lower than the recommendation of Jensen et al. (1988), according to which in pigs a plasma vitamin E concentration of $3 \mathrm{mg} / \mathrm{L}$ is required for optimal immunocompetence.

The decline of plasma vitamin E concentration observed after carotene supplementation may be due to functional co-operation and/or equalisation between the two lipophilic members of the non-enzymatic antioxidant system, despite the fact that the beta-carotene supplementation did not cause carotenaemia in pigs showing physiologically low retinoid and carotenoid levels (Bárdos, 1987). The decline of vitamin E level after beta-carotene supplementation has also been observed in similarly hypocarotenoid laboratory animals such as mice (Xu et al., 1992).

Exogenous nucleotides and purine/pyrimidine bases also bring about an increase in cellular immune response, since, by forming a pool, they have the capacity to fulfil the increased requirements with respect to metabolism and nucleic acid synthesis of proliferation and blastogenesis (Carver, 1994).

Restriction of nucleotides suppressed the production of interleukin-2 following Con A stimulation in mice. This suggests that $\mathrm{T}$ lymphocytes require exogenous nucleotides (Gil and Uauy, 1989). According to Kulkarni et al. (1994), a nucleotide-free diet decreased primarily the T-cell immune response, as indicated by the diminished response of lymphocytes to Con A and PHA as well as their unchanged response given to lipopolysaccharide mitogen. They found that the extent of skin reaction induced by the intradermal injection of different antigens (sheep red blood cell suspension, purified protein) significantly decreased in mice kept on a nucleotide-free diet and then increased after the diet had been supplemented with RNA or uracil.

The compounds added to the diet in this study had no positive effect on the in vivo cell-mediated immune response, presumably because of the low amount added compared to the concentration in the unsupplemented diet. The less expressed skin reaction observed in the carotene group in comparison to the control and the nucleotide groups may have been due to the negative influence exerted on the vitamin $\mathrm{E}$ level by beta-carotene and by vitamin A. 
The possible variance existing between the findings of this experiment and the results reported in the literature are probably attributable to differences in the mode of application and in the dose of the substances supplemented.

The immunomodulating effect of beta-carotene and dietary nucleotides may have practical importance primarily in young animals, in disease and stress conditions. Practical applicability is conditional upon determination of the required dose, which depends on the species, age and physiological status, as well as upon the exploration of interactions existing between other components of the diet.

\section{Acknowledgement}

Financial support for this research project was provided by the Foundation for Higher Education and Research in Hungary (project no. AMFK 137/96).

\section{References}

Barankiewicz, J. and Cohen, A. (1987): Purine nucleotide metabolism in phytohemagglutinininduced human T lymphocytes. Arch. Biochem. Biophys. 258, 167-175.

Bárdos, L. (1987): Isolation of the retinol binding protein (RBP) from the serum of farm animals (in Hungarian). Magyar Állatorvosok Lapja 42, 51.

Bendich, A. and Shapiro, S. S. (1986): Effect of $\beta$-carotene and canthaxanthine on immune responses of the rat. J. Nutr. 116, 2254-2262.

Biesalski, H., Greiff, H., Brodda, K., Hafner, G. and Bassler, K. H. (1986): Rapid determination of vitamin A (retinol) and vitamin E ( $\alpha$-tocopherol) in human serum by isocratic adsorption HPLC. Int. J. Vit. Nutr. Res. 56, 319-327.

Blair, R., Facon, M., Bildfell, R. J., Owen, B. D. and Jacob, J. P. (1996): Tolerance of young pigs for dietary vitamin $A$ and $\beta$-carotene, with special reference to the immune response. Can. J. Anim. Sci. 76, 121-126.

Blecha, F. (1988): Immunomodulation: A means of disease prevention in stressed livestock. J. Anim. Sci. 66, 2084-2090.

Burton, J. L., Mallard, B. A. and Mowat, D. N. (1993): Effects of supplemental chromium on immune responses of periparturient and early lactation dairy cows. J. Anim. Sci. 71, 1532-1539.

Carver, J. (1994): Dietary nucleotides: Cellular immune, intestinal and hepatic system effects. J. Nutr. 124, 144S-148S.

Chew, B. P., Wong, T. S. and Michal, J. J. (1993): Uptake of orally administered $\beta$-carotene by blood plasma, leukocytes, and lipoproteins in calves. J. Anim. Sci. 71, 730-739.

Chew, B. P., Wong, T. S., Michal, J. J., Standaert, F. E. and Heirman, L. R. (1991a): Kinetic characteristics of $\beta$-carotene uptake after an injection of $\beta$-carotene in pigs. J. Anim. Sci. 69, 4883-4891.

Chew, B. P., Wong, T. S., Michal, J. J., Standaert, F. E. and Heirman, L. R. (1991b): Subcellular distribution of $\beta$-carotene, retinol, and $\alpha$-tocopherol in porcine lymphocytes after a single injection of $\beta$-carotene. J. Anim. Sci. 69, 4892-4897.

Daniel, L. R., Chew, B. P., Tanaka, T. S. and Tjoelker, L. W. (1991a): $\beta$-carotene and vitamin A effects on bovine phagocyte function in vitro during the peripartum period. J. Dairy Sci. 74, 124-131.

Daniel, L. R., Chew, B. P., Tanaka, T. S. and Tjoelker, L. W. (1991b): In vitro effects of ß-carotene and vitamin A on peripartum bovine peripheral blood mononuclear cell proliferation. J. Dairy Sci. 74, 911-915. 
Finch, J. M. and Turner, R. J. (1996): Effects of selenium and vitamin E on the immune responses of domestic animals. Res. Vet. Sci. 60, 97-106.

Gil, A. and Uauy, R. (1989): Dietary nucleotides and infant nutrition. J. Clin. Nutr. Gastroenterol. 4, 145-153.

Hoskinson, C. D., Chew, B. P. and Wong, T. S. (1989): Effects of $\beta$-carotene (BC) and vitamin A (VA) on mitogen-induced lymphocyte proliferation in the pig in vivo. FASEB J. 3, A663.

Jensen, M., Fossum, C., Ederoth, M. and Hakkarainen, R. (1988): The effect of vitamin E on the cell-mediated response in pigs. J. Vet. Med. B 35, 549-555.

Kornegay, E. T., Lindemann, M. D. and Ravindran, V. (1993): Effects of dietary lysine levels on performance and immune response of weanling pigs housed at two floor space allowances. J. Anim. Sci. 71, 552-556.

Kulkarni, A. D., Rudolph, F. B. and Van Buren, Ch. T. (1994): The role of nucleotides in immune function: A review. J. Nutr. 124, 1442S-1446S.

Mayne, S. T. and Parker, R. S. (1986): Subcellular distribution of dietary $\beta$-carotene in chick liver. Lipids 21, 164-169.

Michal, J. J., Heirman, L. R., Wong, T. S. and Chew, B. P. (1994): Modulatory effects of dietary $\beta$ carotene on blood and mammary leukocyte function in periparturient dairy cows. J. Dairy Sci. 77, 1408-1421.

Nagahata, H., Fukuta, K. and Noda, H. (1987): Application of the fluorometric DNA quantitative assay using 4,6-diamine-2-phenylindole for the evaluation of lymphocyte blastogenic response. Res. Vet. Sci. 42, 331-333.

NRC (1988): Nutrient Requirements of Swine. National Research Council - National Academy of Sciences, Washington, DC. p. 93.

Pérignon, J. L., Bories, D. M., Houllier, A. M., Thuillier, L. and Cartier, P. H. (1987): Metabolism of pyrimidine bases and nucleosides by pyrimidine-nucleoside phosphorylases in cultured human lymphoid cells. Biochim. Biophys. Acta 928, 130-136.

Schweigert, F. J., Rosival, I., Rambeck, W. A. and Gropp, J. (1995): Plasma transport and tissue distribution of $\left[{ }^{14} \mathrm{C}\right]$ beta-carotene and $\left[{ }^{3} \mathrm{H}\right]$ retinol administered orally to pigs. Int. J. Vit. Nutr. Res. 65, 95-100.

Willett, W. C., Stampfer, M. J., Underwood, B. A., Taylor, J. O. and Hennekens, C. H. (1983): Vitamins A, E and carotene: Effects of supplementation on their plasma levels. Am. J. Clin. Nutr. 38, 559-564.

Xu, M. J., Plezia, P. M., Alberts, D. S., Emerson, S. S., Peng, Y. M., Sayers, S. M., Liu, Y., Rittenbaugh, C. and Gensler, H. L. (1992): Reduction in plasma or skin alpha-tocopherol concentration with long-term oral administration of beta-carotene in humans and mice. J. Natl. Cancer Inst. 84, 1559-1565. 